\title{
Concomitant chemopreventive and antibacterial effects of some Iranian plants from the genus Cousinia (Asteraceae)
}

\author{
Ahmad Reza Shahverdi ${ }^{1 *}$, Mohammad Reza Khorramizadeh ${ }^{2}$, Farideh Attar ${ }^{3}$, Farshid \\ Saadat $^{4}$, Sepideh Vahid ${ }^{1}$, Ahmad Ghahraman ${ }^{3}$ \\ ${ }^{1}$ Department of Pharmaceutical Biotechnology and Biotechnology and Plant Research Centers, Faculty of \\ Pharmacy, Medical Sciences, University of Tehran, P.O.Box 14155/6451, Tehran, Iran, \\ ${ }^{2}$ Department of Pathobiology, School of Public Health, Medical Sciences, University of Tehran, Tehran, Iran, \\ ${ }^{3}$ Central Herbarium of Tehran University, University College of Sciences, Tehran University, Tehran, Iran, \\ ${ }^{4}$ Department of Immunology, Faculty of Medicine, Gilan University of Medical Sciences,
} Rasht, Iran

\begin{abstract}
RESUMO: "Efeitos quimiopreventivo e antibacteriano concomintantes de algumas plantas iranianas do gênero Cousinia (Asteraceae)”. Durante os últimos anos, várias espécies de Cousinia (Asteraceae) têm sido identificadas no Irã. No entanto, dados acerca de suas atividades biológicas permanecem limitados. O principal propósito desta pesquisa foi avaliar a potencial citotoxidade e os efeitos inibitórios de metaloproteinases da matriz (MMP) de sete extratos etanólicos de Cousinia utilizando um modelo de linhagem celular (Fibrosarcoma-WEHI 164). Além disso, investigamos a atividade antibacteriana destes extratos etanólicos de Cousinia, utilizando o método de difusão em disco. Dentre os extratos etanólicos, o extrato total de $C$. sulabadensis promoveu inibição significativa da atividade de MMP de maneira dose-resposta $(49,2 \pm 0,51, p<0,05)$. Todavia, este extrato exibiu o menor efeito de citotoxicidade em todas as concentrações testadas. A concentração necessária para produzir uma taxa de $50 \%$ de morte celular (IC50) com C. shulabadensis foi 304,5 $\pm 0,61 \mu \mathrm{g} / \mathrm{mL}$. A IC50 calculada para a citotoxicidade dos outros extratos de espécies de Cousinia situou-se entre 18,4 $\pm 0,59$ e 87,9 $\pm 0,58 \mu \mathrm{g} / \mathrm{mL}$. A maior atividade antibacteriana foi observada para o extrato total de Cousinia phyllocephala. Em conclusão, este estudo corrobora que espécies de Cousinia mostram uma notável inibição da atividade de metaloproteinases da matriz. Os concomitantes efeitos inibitórios de MMP e baixa citotoxicidade observados em $C$. sulabadensis devem direcionar este extrato para futuros estudos de potenciais fitoterápicos anti-invasivos.
\end{abstract}

Unitermos: Cousinia, citotoxicidade, IC50, zimografia, antibacteriano, linhagem celular WEHI 164.

\begin{abstract}
During the past several years, various species of Cousinia (Asteraceae) have been authenticated in Iran. However, data concerning their biological activities remain limited. The main purpose of this research was to assess potential cytotoxicity and matrix metalloproteinases (MMP) inhibitory effects of seven ethanol extracts of Cousinia using a cell line model (FibrosarcomaWEHI 164). We further investigated the antibacterial activity of these Cousinia ethanol extracts, using disk diffusion method. Among the ethanol extracts, the total extract of $C$. sulabadensis elicited significant inhibition of MMP activity in a dose-response fashion $(49.2 \pm 0.51, \mathrm{p}<0.05)$. However, this extract exhibited the lowest cytotoxicity effect at all tested concentrations. The concentration necessary to produce a 50\% cell death rate (IC50) with C. shulabadensis was 304.5 $\pm 0.61 \mu \mathrm{g} / \mathrm{mL}$. The calculated IC50 for cytotoxicity of the other Cousinia species extracts ranged between $18.4 \pm 0.59$ to $87.9 \pm 0.58 \mu \mathrm{g} / \mathrm{mL}$. The highest antibacterial activity was observed for the total extract of Cousinia phyllocephala. In conclusion, this study supports that Cousinia species display a remarkable inhibition of matrix metalloproteinases activity. The concomitant MMPinhibitory and low cytotoxicity effects observed in C. sulabadensis might coin this extract for future potential anti-invasive herbal medicine studies.
\end{abstract}

Keywords: Cousinia, cytotoxicity, IC50, zymography, antibacterial, WEHI 164 cell line.

\section{INTRODUCTION}

The genus Cousinia (Asteraceae) is found worldwide and comprises approximately 672 species, of which about 235 occur in central, western, eastern and southeastern regions of Iran (Sheidai et al., 2006). In 
recent years some species of this genus (listed in Table 1) have also been reported from different parts of Iran (Attar, 2000). In our previous study, we observed some cytotoxicity and matrix metalloprotainases (MMPs) inhibitory effects of Cousinia shulabadensis (Shahverdi et al., 2007). However, no comparative study has been performed on the biological activities of ethanol extracts derived from various Cousinia species. It is noteworthy that MMPs play an important role in several pathologic processes, such as malignancy, in which they facilitate invasion and metastasis. Thus, they could be targets for anticancer and anti invasive therapies (Heath; Grochow, 2000; Tate et al., 2004).

In the present study, we setup a comparative assessment on potential cytotoxicity, MMP-inhibitory and antibacterial effects of seven Cousinia ethanol extracts.

\section{MATERIAL AND METHODS}

\section{Plant materials}

The plants listed in Table 1 were collected from different sites throughout Iran from 1993 to 1999 and authenticated by Dr. F. Attar and Dr. A. Ghahraman (Central Herbarium of Tehran University; Tehran, Iran). Voucher specimens were deposited at the Herbarium of Tehran University as follows: Cousinia onopordioides (TU 21890), Cousinia rechingerae (TU 28689), Cousinia Hypopolia (TU 21904), Cousinia sulabadensis (TU 21876), Cousinia phyllocephala (TU 21825), Cousinia smirnovii (TU 21864) and Cousinia verbascifolia (TU 21907).

\section{Preparation of plant extracts}

The plants were air-dried at room temperature and then pulverized. The ethanol $(80 \% \mathrm{v} / \mathrm{v})$ extracts were prepared by maceration of the powders $(100 \mathrm{~g} /$ sample) for $72 \mathrm{~h}$ with three changes of solution at room temperature. For each plant sample, the combined solvent extracts were evaporated to yield brownish viscous residues and stored in labeled, screw-capped bottles at $20{ }^{\circ} \mathrm{C}$ until used for further assay. All experiments were performed based on the dry mass of the concentrated extracts which were dissolved in dimethyl sulfoxide/ ethanol (1:1) at concentration of $1 \mathrm{mg} / \mathrm{ml}$ for cellular assays. In a parallel set of experiment, other stock solutions $(100 \mathrm{mg} / \mathrm{mL})$ were prepared in ethanol (80 \% $\mathrm{v} / \mathrm{v}$ ) for antibacterial assays.

\section{Antibacterial activity}

The antibacterial activity of the ethanol extracts of different species of Cousinia plants were studied against the following strains: Bacillus subtilis, Escherichia coli, Salmonella typhi and Staphylococcus aureus. All test strains were kindly provided by the Laboratory of Microbial Quality Control, Department of Food and Drug, Faculty of Pharmacy, Medical Sciences/ University of Tehran. Confirmation of the identity of the isolates was conducted using conventional morphological, as well as biochemical, methods. A single colony of bacteria was grown overnight in a MüllerHinton Broth (MHB) medium (Difco, USA) on a rotary shaker (200 rpm) at $35^{\circ} \mathrm{C}$. The inocula were prepared by diluting the overnight cultures with $0.9 \% \mathrm{NaCl}$ to a 0.5 McFarland standard. A McFarland 0.5 turbidity standard is prepared by mixing $0.05 \mathrm{ml}$ of $1.175 \%$ barium chloride dihydrate $\left(\mathrm{BaCl}_{2}, 2 \mathrm{H}_{2} \mathrm{O}\right)$, with $9.95 \mathrm{ml}$ of $1 \%$ sulfuric acid. They were then applied to the Müller-Hinton agar (Difco, USA) plates along with the disks containing different concentrations of ethanol extracts of Cousinia species (2,4,6 and $8 \mathrm{mg})$. After incubation at $35^{\circ} \mathrm{C}$ for $18 \mathrm{hrs}$, the zones of growth inhibition were measured. The assays were performed in triplicate. The MIC was defined as the lowest drug concentration resulting in a clear zone of growth inhibition around the disc after the conventional incubation period (Pettit et al., 2003).

\section{Cell culture}

The Fibrosarcoma cell line (WEHI 164) was seeded, in triplicate, at initial density of $3 \times 10^{4} \mathrm{cells} /$ well in 96-well tissue culture plates. Cells were maintained in RPMI-1640 (Sigma, St. Louis, USA) medium supplemented with $10 \%$ fetal calf serum (Sigma, Germany), penicillin at 100 units/mL, and streptomycin at $100 \mu \mathrm{g} / \mathrm{mL}$, under $5 \% \mathrm{CO}_{2}, 37{ }^{\circ} \mathrm{C}$ and saturated humidity. The Fibrosarcoma-WEHI 164 cell line was obtained from the National Cell Bank of Iran (NCBI), Pasteur Institute of Iran in Tehran, Iran.

\section{Dose-response analysis}

Triplicate, two-fold dilutions of plant extracts were transferred to overnight cultured cells. According to published data, piroxicam (Sigma, St. Louis, USA) was used as the cytotoxic reference drug (Mirshafiey et al., 2004) at the concentrations of $10,20,40$, and $80 \mu \mathrm{g} /$ $\mathrm{mL}$. Non-treated cells were used as control. Cells were cultured overnight and then subjected to colorimetric assay. Cytotoxicity was expressed as the percentage of viable cells at different concentrations of samples. The IC 50 was calculated as the dose at which a $50 \%$ cell death rate occurred relative to the untreated cells. The corresponding supernatants of the cultured cells were used for zymoanalysis.

\section{Colorimetric cytotoxicity assay}

This method was carried out to assess the potential effects of plants extracts on cell viability 
according to the published data (Shahverdi et al., 2006). After each experiment, cells were washed three times with ice-cold phosphate buffered saline (PBS), $\mathrm{pH} 7.2$, followed by fixation in $5 \%$ formaldehyde (Merck, Germany) solution. Fixed cells were washed three times and stained with $1 \%$ crystal violet. The stained cells were washed, lysed and solublised with $33.33 \%$ acetic acid solution. The density of developed purple color was read at $580 \mathrm{~nm}$ using a conventional ELISA reader instrument.

\section{Gelatinase zymography}

This technique is mainly used for the detection of gelatinases, MMP-2 and MMP-9. The zymography procedure was adopted according to our previous publication (Khorramizadeh et al., 2005). It is extremely sensitive because levels of $10 \mathrm{pg}$ of MMP-2 can be detected. Briefly, protein-content adjusted (normalized) aliquots of conditioned media, in triplicate, were subjected to sodium dodecyl sulfate polyacrilamide gel
electrophoresis(SDS-PAGE) containing $2 \mathrm{mg} / \mathrm{mL}$ gelatin (Merck, Germany). Electrophoresis was performed for 3 hours at a constant voltage of 80 volts in tris-borate buffer media. After electrophoresis, gels were gently washed three times with $2.5 \%$ Triton X-100 solution to remove SDS. The gel slabs were then incubated at $37^{\circ} \mathrm{C}$ overnight in $0.1 \mathrm{M}$ Tris HCL gelatinase activation buffer (PH 7.4) containing $10 \mathrm{mM} \mathrm{CaCl2}$. Staining was performed with $0.5 \% \mathrm{w} / \mathrm{v}$ coomassie brilliant blue dye (Merck, Germany) in absolute ethanol/glacial acetic acid (1:1) solution followed by intensive destaining in the same solution without dye. MMP-2 proteolysis areas appeared as clear bands against a blue background in the gels.

Using a UVI pro gel documentation system (GDS-8000, Cambridge, UK), quantitative evaluation of both surface and intensity of lysing bands (mean area density), on the basis of grey levels, were compared relative to non-treated control wells and expressed as relative expression of gelatinolytic activity. The IC50 for the MMP inhibitory effect was calculated as those

Table 1. Plant materials submitted to the antibacterial activity assay based on their sites of collection and their minimum inhibitory concentrations (MIC) against the test strains.

\begin{tabular}{|c|c|c|c|c|c|}
\hline \multirow{2}{*}{ Species } & \multirow{2}{*}{ Site of collection } & \multicolumn{4}{|c|}{ MIC (mg/disk) } \\
\hline & & S. aureus & B. subtilis & E. coli & S. typhi \\
\hline C. onopordioides & Shahrod, Semnan & $>8$ & $>8$ & $>8$ & $>8$ \\
\hline C. rechingerae & Bojnord, Khorasan & $>8$ & $>8$ & $>8$ & $>8$ \\
\hline C. hypopolia & Bojnord, Khorasan & 8 & 8 & $>8$ & $>8$ \\
\hline C. sulabadensis & Sholabad, Lorestan & $>8$ & $>8$ & $>8$ & $>8$ \\
\hline C. phyllocephala & Drod, Khoram abad & 4 & 4 & $>8$ & $>8$ \\
\hline C. smirnovii & Sarakhs, Khorasan & $>8$ & $>8$ & $>8$ & $>8$ \\
\hline C. verbascifolia & Sarakhs, Khorasan & 8 & 8 & $>8$ & $>8$ \\
\hline
\end{tabular}

Table 2. The inhibitory potentials of the 7 different species of Cousinia on the viability of Fibrosarcoma-WEHI 164 and matrix metalloprotainases expression. Sample size $=7$, repetitions $=3$, calculated $\mathrm{p}<0.05$

\begin{tabular}{rlcc}
\hline No & \multicolumn{1}{c}{ Test samples } & $\begin{array}{c}\text { IC 50 value for } \\
\text { Cytotoxicity } \\
(\mu \mathrm{g} / \mathrm{mL})\end{array}$ & $\begin{array}{c}\text { IC 50 value for MMPs activity } \\
(\mu \mathrm{g} / \mathrm{mL})\end{array}$ \\
\hline 1 & Reference drug (piroxicam) & $87.9 \pm 0.58$ & $172.8 \pm 0.53$ \\
2 & C. rechingerae & $31.6 \pm 0.66$ & $24.9 \pm 0.52$ \\
3 & C. onopordioides & $30.5 \pm 0.81$ & $29.2 \pm 0.56$ \\
4 & C. phyllocephala & $30.0 \pm 0.56$ & $27.9 \pm 0.52$ \\
5 & C. sulabadensis & $304.5 \pm 0.61$ & $49.2 \pm 0.51$ \\
6 & C. hypopolia & $24.4 \pm 0.71$ & $31.0 \pm 0.56$ \\
7 & C. verbascifolia & $18.4 \pm 0.59$ & $32.6 \pm 0.50$ \\
8 & C. smirnovii & $25.9 \pm 0.69$ & $35.9 \pm 0.48$ \\
\hline
\end{tabular}




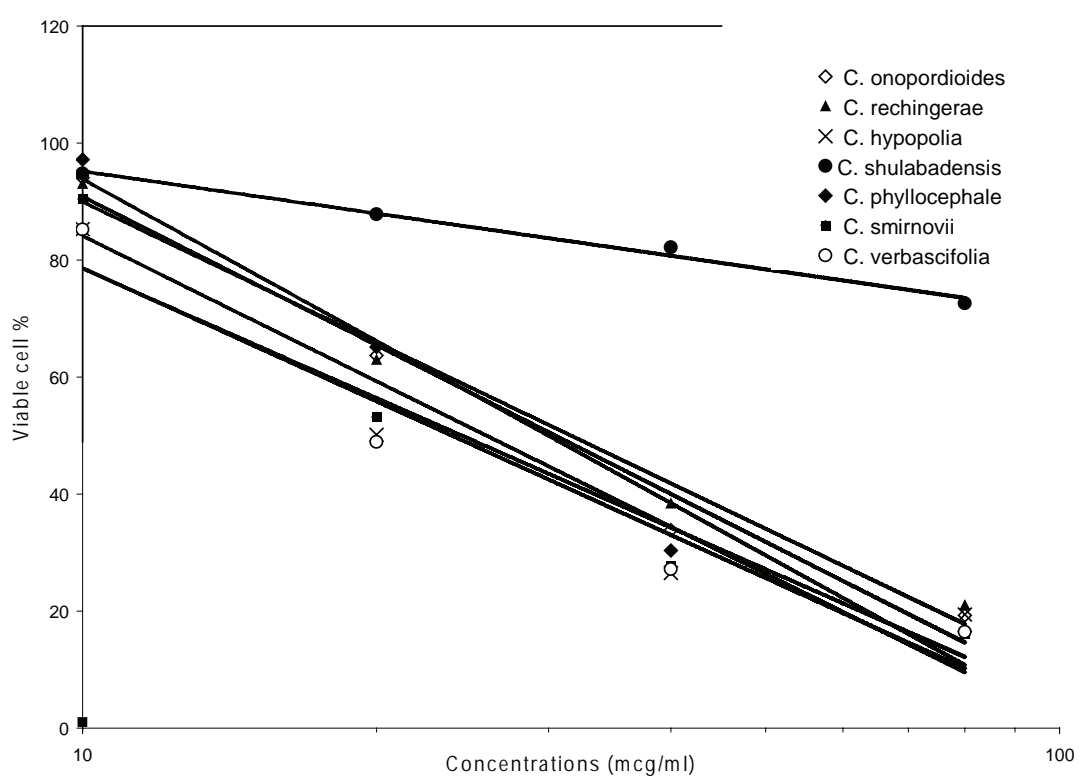

Figure 1. The effects of the ethanol extracts of different species of Cousinia on the viability of Fibrosarcoma-WEHI 164.

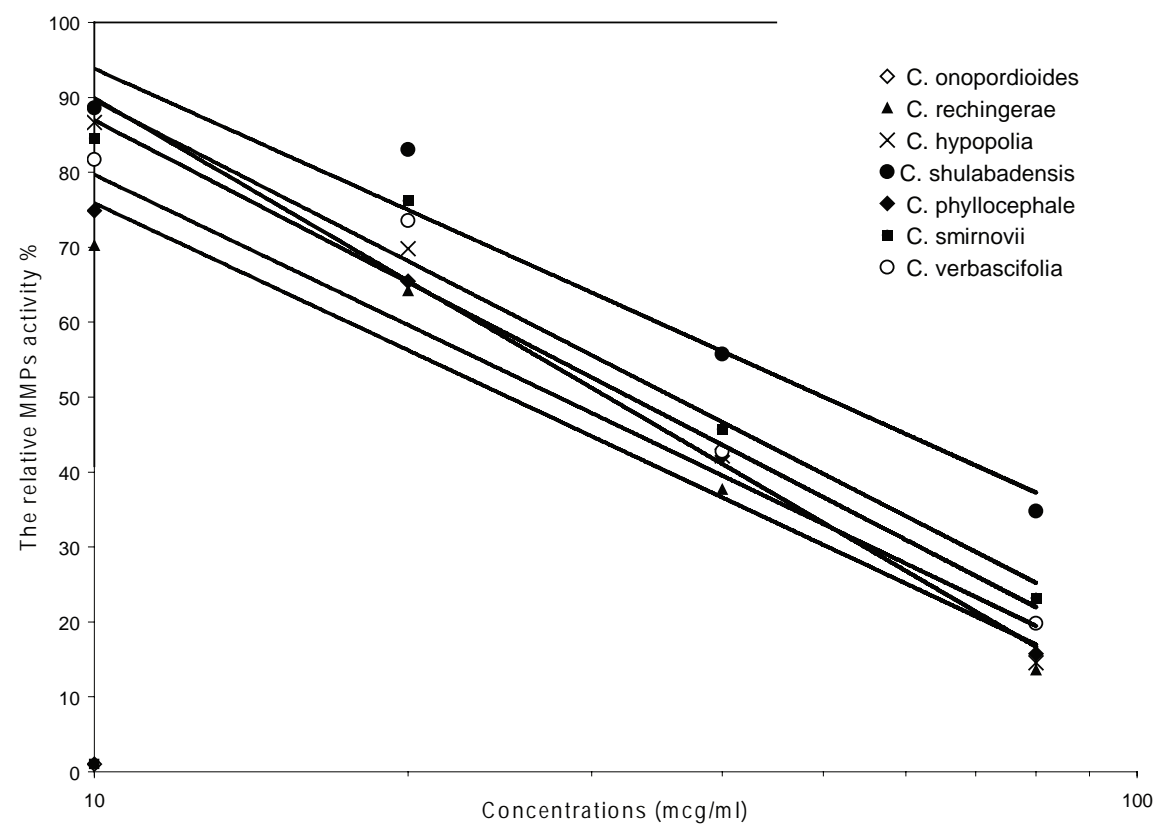

Figure 2. The effects of the ethanol extracts of different species of Cousinia on the matrix metalloprotainases expression.

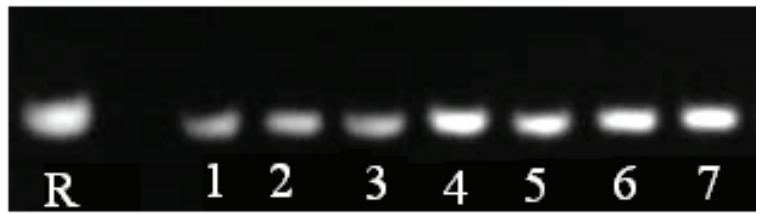

Figure 3. A typical gelatin substrate zymograph showing the effect of seven ethanol extracts of Cousina species as compared to reference drug agent piroxicam. From left to right: piroxicam (R), C. rechingerae (1), C. onopordioides (2), C. phyllocephala (3), C. sulabadensis (4), C. hypopolia(5), C. verbascifolia(6), C. smirnovii (7) 


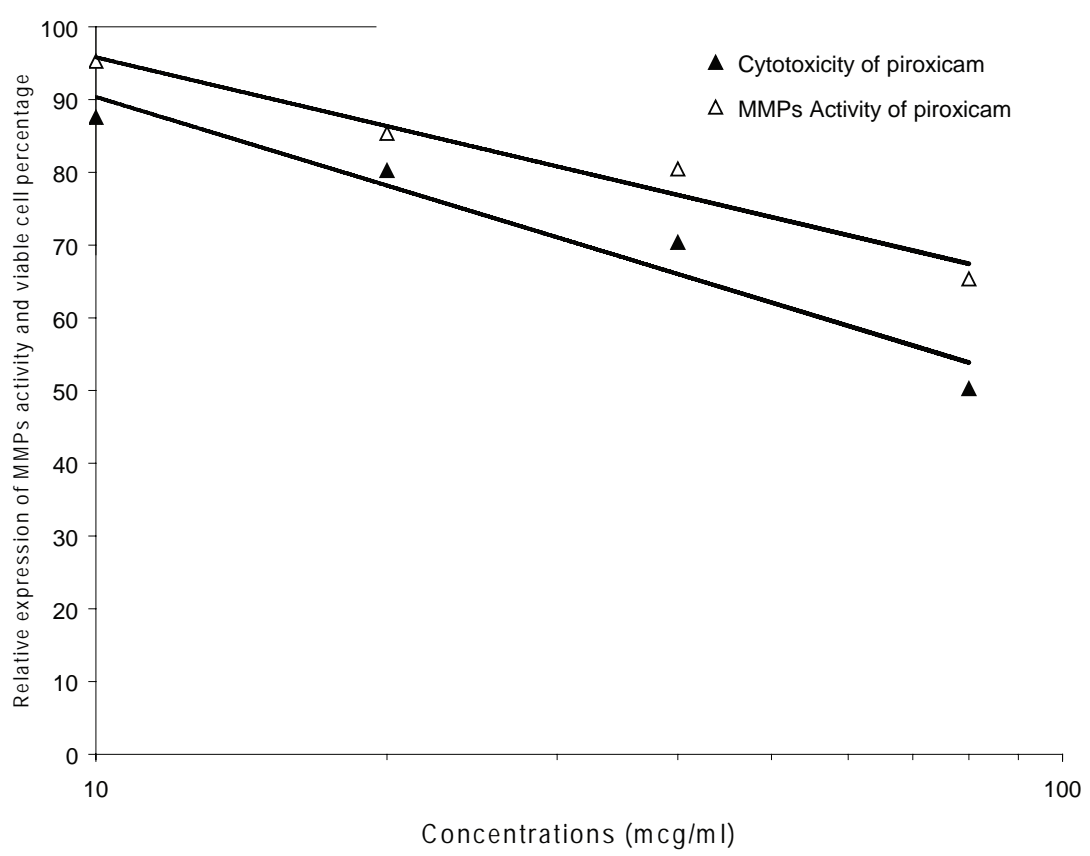

Figure 4. The effects of the reference drug on the Fibrosarcoma-WEHI 164 viability and metalloprotainases expression.

doses at which $50 \%$ of MMP inhibition occurred relative to that of the untreated control cells.

\section{Statistical analysis}

The differences in cell cytotoxicity and gelatinase zymography were compared using the Student's t test. $\mathrm{P}$ values $<0.05$ were considered significant.

\section{RESULTS AND DISCUSSION}

Interest in new species of plants as a source of drug innovation is currently increasing. During the past several years, various species of Cousinia have been authenticated (Attar, 2000). However, data concerning their biological activities remain limited (Shahverdi et al., 2007). In the present study, the ethanol extracts of seven species from the Cousinia genus were evaluated for their antibacterial activity and toxicity against the Fibrosarcoma-WEHI 164 cell line. All plant extracts in this study showed detectable antibacterial activity against test strains (Table 1). As shown in Table 1, the C. phyllocephala ethanol extract represented the most potent antibacterial candidate with MICs of $4 \mathrm{mg}$ for Gram positive bacteria (S. aureus and Bacillus Subtilis). However, this extract showed no activity at this concentration against the E. coli and Salmonella typhi for Gram negative strains (Table 1). The other crude extracts provided from $C$. onopordioides, $C$. rechingerae, C. Hypopolia, C. sulabadensis, C. smirnovii and C. verbascifolia all exhibited antibacterial activity against S. aureus and Bacillus Subtilis with MICs $\geq 8 \mathrm{mg}$, and against E. coli and Salmonella typhi (MIC $>8 \mathrm{mg}$ ).

The cytotoxicity of the total extracts of the Cousinia species and a reference drug (piroxicam) were evaluated in vitro on the fibrosarcoma cell line (WEHI 164) at doses of 10, 20, 40, and $80 \mu \mathrm{g} / \mathrm{ml}$. Our cytotoxicity analysis of the total extracts shows direct dose-response results with the total extracts of different Cousinia; the higher the concentration, the higher the toxicity (Figure 1). The raw data derived from cytotoxicity analyses were transformed to IC50 measurements for statistical comparison (Table 2). The ethanol extracts of $C$. verbascifolia exhibited the cytotoxicity effect as measured by IC50 (18.4 $\pm 0.59, \mathrm{P}$ $<0.05)$. As shown in Figure 1, the lowest cytotoxicity was observed for the total extract of $C$. shulabadensis (304.5 \pm 0.61$)$. C. shulabadensis total extract showed only $18 \%$ inhibition of cell growth at its highest dose of treatment $(80 \mu \mathrm{g} / \mathrm{mL})$. At lower dose levels (less than 80 $\mu \mathrm{g} / \mathrm{mL}$ ), this plant extract showed minimal cytotoxicity with a viability percentage of more than $85 \%$. In contrast, other Cousinia species showed comparatively higher cytotoxic effect, especially at concentrations greater than $10 \mu \mathrm{g} / \mathrm{mL}$. The concentration necessary to produce $50 \%$ cell death was $304.5 \pm 0.61 \mu \mathrm{g} / \mathrm{mL}$ for the ethanol extract of $C$. shulabadensis, while a range of $18.4 \pm 0.59$ to $87.9 \pm 0.58 \mu \mathrm{g} / \mathrm{mL}$ concentrations of the other plant extracts and the reference drug produced the same effect (Table 2).

Subsequently, the MMPs-inhibitory properties 
of the ethanol extracts of different species of the genus Cousinia were investigated at dose levels of 10, 20, 40 and $80 \mu \mathrm{g} / \mathrm{mL}$ by zymoanalysis. The inhibitions of the total extracts of the tested plants on MMPs activity expressed by fibrosarcoma-WEHI 164 cells are presented in Figure 2. Moreover, Figure 3 depicted a typical zymogram gel showing the proteolytic effects of different samples against the reference drug (piroxicam). It has been postulated that gelatinase (MMP-2) activity in these cells is associated with their metastatic properties (Khorramizadeh et al., 2005). Therefore, assessment of either MMP-2 or MMP-9 activity in cancer cells could be used for in vitro analysis of metastasis phenotype. Figure 4 shows the cytotoxicity and MMP inhibitory effects of the reference drug. Based on zymogeraphy analysis of piroxicam, a reduction of MMP expression was associated with an increasing concentration of this drug. This finding is in accordance with previous studies (Mirshafiey et al., 2004). The reference drug exhibited less MMP inhibitory effects at all tested concentrations. The IC50 values for total extracts and the reference drug (the concentration that inhibits the invasion of the WEHI 164 cells by $50 \%$ relative to untreated control) were calculated and reported in Table 2. At the tested concentrations, $C$. Shulabadensis ethanol extract showed a relatively lower MMP inhibitory activity, as compared to the other plant extracts listed in Table 2. However, the extracts derived from plant species other than $C$. Shulabadensis are too toxic to use at high doses, where their considerable reduction of MMP expression is mostly associated with total cell death (Figure 1). In other words, the total extract of $C$. sulabadensis did not show high toxicity at all tested concentrations, but rather demonstrated a significant inhibition of MMP activity as evaluated with IC50 parameter.

This is thefirstreporton theantimicrobialactivity and comparative chemopreventive study of different species of Cousinia collected from various areas of Iran. The ethanol extracts of these plants showed detectable antimicrobial activity against some Gram (+) and Gram (-) bacteria, ranging from MIC 4 to MIC $>8$. The highest antibacterial activity was observed for the total extract of C. phyllocephala. These extracts were also evaluated for their cytotoxicity as well as their impact on MMP activity using a cell line model (Fibrosarcoma-WEHI 164). The total extracts of the plants demonstrated a significant inhibition of cell viability in a dose-response fashion. The most cytotoxicity was observed for the ethanol extract of $C$. verbascifolia in this tumor cell line. Although the activities of other plant extracts on MMP expression were higher than that of $C$. sulabadensis, these other plant extracts show obvious toxicity at all tested concentrations. Conversely, these results indicate that the ethanol extract of $C$. sulabadensis presents anti-MMP properties with simultaneous low cytotoxicity. According to the critical role of MMPs in many pathological disorders, these extracts represent a promising approach to the treatment of a variety of malignant and inflammatory disorders. Based on our obtained results, we suggest $C$. sulabadensis as the best candidate for further anti-metastatic and/or antiinflammation studies.

Future work, however, should focus on the identification and purification of active compound(s) to gain a better perspective of its properties.

\section{ACKNOWLEDGMENTS}

The authors are grateful for the financial support provided by the Deputy of Research, Medical Sciences/University of Tehran (grant No. 132/11654).

\section{REFERENCES}

Attar F 2000. Systematic study on Cousinia section in Iran. A Ph.D. Thesis, University of Tehran, Tehran, Iran.

Heath EI, Grochow LB 2000. Clinical potential of matrix metalloprotease in cancer therapy. Drugs 59: 10431055.

Khorramizadeh MR, Aalizadeh N, Pezeshki M, Ghahary A, Zeraati H, Berahmeh A, Safa O, Saadat F 2005. Determination of gelatinase A using a modified indirect hemagglutination assay in human prostate cancer screening and assessment of its correlation with prostate-specific antigen parameters. Int $J$ Urol 12: 637-643.

Mirshafiey A, Vaezzadeh F, Khorramizadeh MR, Saadat F 2004. Effect of piroxicam on matrix metalloproteinase 2 and apoptosis. Int $J$ Tissue React 26: 1-7.

Pettit RK, Cage GD, Pettit GR, Liebman JA 2003. Antimicrobial and cancer cell growth inhibitory activities of $3 \beta$ acetoxy-17 $\beta$-(l-prolyl)amino- $5 \alpha$-androstane in vitro. Int J Antimicrob Agents 15: 299-304.

Shahverdi AR, Khoramizadeh MR, Ghahramani MH, Golyaee A, Attar F, Gharaman A 2007. Chemopreventive effect of Cousinia shulabadensis ethanol extract. Afr J Trad CAM 4: 12-16.

Shahverdi AR, Saadat F, Khorramizadeh MR, Iranshahi M, Khoshayand MR 2006. Two matrix metalloproteinases inhibitors from Ferula persica var. persica. Phytomedicine 13: 712-717.

Sheidai M, Mehdigholi K, Ghahreman A, Attar F 2006. Cytogenetic study of the genus Cousinia (Asteraceae, section Serratuloideae) in Iran. Genet Mol Biol 29: 117-121.

Tate P, God J, Bibb R, Lu Q, Larcom LL 2004. Inhibition of metalloproteinase activity by fruit extracts. Cancer lett 212: 153-158. 